\title{
Taxes and the Choice of Organizational Form in Late Nineteenth Century Japan
}

\author{
KAZUKI ONJI AND JoHn P. TANG
}

\begin{abstract}
How do changes to taxation policy affect the organizational choices of firms? Using historical firm data constructed from Japanese corporate genealogies, we examine the short-run impact of introducing a personal income tax (PIT) in 1887 on tax-motivated incorporation. Between 1880 and 1892, we find that the introduction of PIT increased the share of incorporated firms by more than 3 percentage points, indicating firms chose their organizational structure to avoid new taxation. Furthermore, our results suggest that a corporate income tax may have acted as a backstop to maintain revenue collected through PIT.
\end{abstract}

\begin{abstract}
A firm's decision to incorporate may have significant tax consequences both for itself and for the governments that earn revenues from specific organizational forms. For example, incorporation may reduce taxes collected from personal income by shielding assets under a corporate structure (Hanlon and Heitzman 2010); expand the corporate tax base in the face of tax competition that reduces corporate tax rates (de Mooij and Nicodème 2008); or motivate entrepreneurship by providing a risk-sharing mechanism with the government as a silent partner (Cullum and Gordon 2007). However, given the complexity of tax systems and the interaction between different types of taxes, it is difficult to evaluate the impact of individual policies on firm behavior.

This ambiguity is reflected in empirical studies on this topic. Some scholarship finds taxes have a modest influence on organizational form, with non-tax factors like limited liability status and external finance considerations inducing incorporation, whereas administrative simplicity
\end{abstract}

The Journal of Economic History, Vol. 77, No. 2 (June 2017). (C) The Economic History Association. All rights reserved. doi: 10.1017/S002205071700047X

Kazuki Onji is Associate Professor, Osaka University, Graduate School of Economics, 1-7 Machikaneyamacho, Toyonaka Osaka 5600043, Japan. E-mail: kazuki.onji@econ.osaka-u.sc.jp. John P. Tang is Senior Lecturer, Australian National University, Research School of Economics, 26 LF Crisp Building, Acton ACT 2601, Australia. E-mail: john.tang@anu.edu.au

Thanks to Paul Rhode, William Collins, Li Liu, two anonymous referees, and seminar participants at ANU(RSE), AJRC, UCL(CORE), NTA 2015 for comments and suggestions that significantly improved this paper. Onji has received funding for this research from the GSE, Osaka University and MEXT/JSPS KAKENHI Grant Number 15K03510. Tang has received funding for this research from the Australian Research Council (DE120101426). The authors would like to thank Jun Imaki and Koji Asano for helpful research assistance and translation support. A previous version of this paper was circulated under the title "A nation without a corporate income tax: Evidence from nineteenth century Japan.” All remaining errors are ours. 


\section{Taxes and the Choice of Organizational Form in Japan 441}

and fewer disclosure requirements encourage a sole proprietorship structure (Gordon and MacKie-Mason 1994; Mackie-Mason and Gordon 1997; Goolsbee 1998). More recent work raises concern over the robustness of results that were based on time series analysis of aggregate corporate share, and instead employs panel data to take advantage of crosssection variation in tax rates across states or countries (Goolsbee 2004; de Mooij and Nicodème 2008; Liu 2014). These studies indicate that the impact of tax considerations may in fact be larger than previously thought, re-opening the debate on the magnitude of tax effects.

An alternative approach, which provides clearer identification, is to examine the effects of introducing a personal income tax (PIT) into an economy without any personal or corporate taxation. This offers a quasiexperimental setting whereby the choice of organizational form before the imposition of a tax should be determined by non-tax factors only. The introduction of PIT changes incentives, offering a discrete pre- and post-tax environment to examine behavioral responses and the importance of taxation on a firm's organizational decision. While attractive in principle, finding an appropriate empirical setting in practice is difficult. This is because industrialized nations started to introduce PIT during the nineteenth century when official statistics on corporations, let alone sole proprietors, are limited or non-existent. ${ }^{1}$

Our article circumvents this data limitation by drawing on qualitative historical firm data during a period when official data do not exist. Using firm-level data from genealogies of major corporations compiled by Shintarō Yagura and Yoshirō Ikushima (1986), these data distinguish between organizational forms (joint-stock corporations, sole proprietors), allowing us to assess the firm-level response to the introduction of PIT in 1887. ${ }^{2}$ While the data have limitations such as firm selection and representativeness, these features work in our favor by acting as a lower bound to our estimates. In particular, given that existing scholarship indicates smaller businesses respond more strongly to changes in tax policy, our over-representation of larger firms will lead to an underestimation of the overall economic impact.

For our analysis, we utilize the time variation in tax incentives created by the introduction of PIT in 1887 as a quasi-experiment and control for the macroeconomic environment and industry-specific trends. The sample period extends from 1880 to 1892 to capture pre- and post-PIT

\footnotetext{
${ }^{1}$ Grossfeld and Bryce (1983) provide a historical account on the origins of income taxes in the United Kingdom, Germany, and the United States.

${ }^{2}$ See Tang $(2011,2013)$ for examples of firm genealogical data analyses.
} 
changes and to exclude influences of the 1893 commercial code reform. Our baseline model uses the firm-year observations in cross-section to test the probability that a firm's organizational choice changes discretely following the PIT introduction. Reduced form estimates suggest that the introduction of PIT increased the incorporation rate in the sample by 3.2 percentage points. In terms of marginal effects, with the top PIT rate of 3 percent, our estimate suggests that a 1 percent increase in a PIT rate increases the share of incorporated firms by an equivalent amount. To check for robustness, we control for unobserved heterogeneity by reconstructing the data into a panel dataset by firm genealogy and industry. ${ }^{3}$ This also allows us to consider the dynamic dependence in organizational forms and provide estimates from dynamic panel regressions. Finally, to account for possible unobserved time shocks, we include a set of macroeconomic variables to control for changes in business conditions as well as consider alternative explanations.

Our results give quantitative support to an issue of long-standing interest to Japanese economic historians, specifically on the issue of hojin nari, or tax-motivated incorporation (Miyamoto 1990) and the overhaul of major firms like the Mitsui zaibatsu (Matsumoto 1979, cited in Nakamura 2010). We also provide estimates for a period preceding other studies that use more aggregate-level data (Takahashi 1956; Nakamura 2010), which is important since the period spanning the PIT introduction is known as the "First Surge of the Corporate Sector" (1886-1889) in Japan. Finally, we explicitly allow for "stickiness" of organizational forms, which has been neglected in the literature. Taken together, our findings indicate that firms actively engaged in tax avoidance through their organizational choices and that it was a factor underlying the rise of the corporate sector during Japan's early industrialization in the Meiji Period.

\section{INTRODUCING A MODERN TAX SYSTEM TO JAPAN}

The Meiji Japanese government replaced the feudal administration in 1867 and pushed for industrialization to catch up with advanced nations. Initially, due to a lack of tariff autonomy, the new government relied on a land tax to finance the modernization of the military and industries, but this generated significant hardship for farmers and peasants during the Matsukata deflationary period in the early 1880s. Against the backdrop

\footnotetext{
${ }^{3}$ The industry panel analysis is most directly comparable to the U.S. studies (e.g., Liu 2014).
} 
Taxes and the Choice of Organizational Form in Japan 443

TABLE 1

EARLY INCOME TAX IN JAPAN

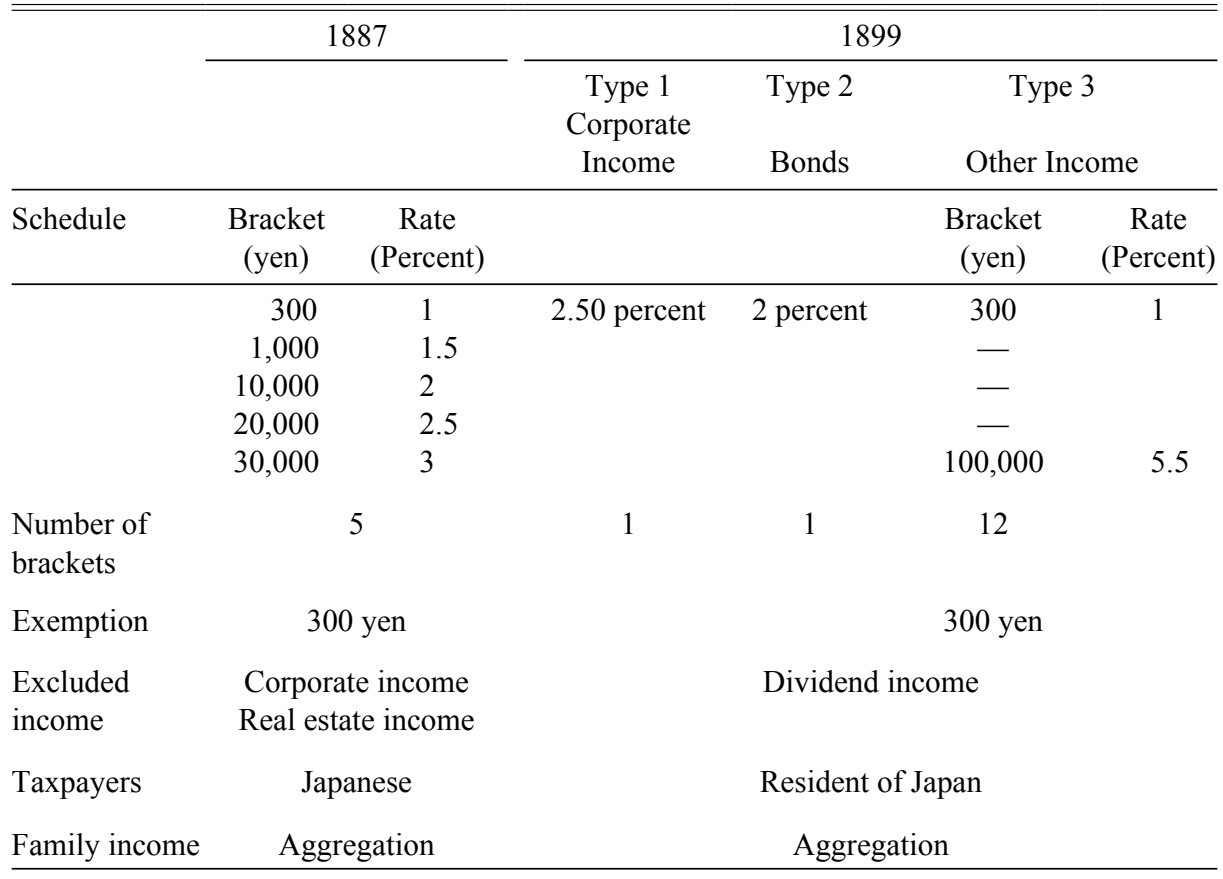

Source: Takagi (2007).

of rising political demand to fund the military and to raise taxes from industrialists, the introduction of a PIT was considered as early as 1884 (Hayashi 1965, p. 299). The Ministry of Finance drafted and sent an income tax proposal to the Prime Minister's Cabinet in January 1887. On February 1887, the proposal was sent to the Senate (Genroin) with some modifications, and the following month, the Income Tax Act (Shotoku Zeihō) was passed, with implementation starting July 1887. Table 1 provides a summary of the main features of the early PIT along with a reform in 1899.

Initially, tax rates ranged from 1 to 3 percent with a large exemption of 300 yen, almost ten times the average annual income per person (Japan Statistical Association 1987). The rate schedule was so-called simple progressive where taxpayers faced discrete tax increases at thresholds. For example, the tax liability increased from zero to three yen at the first threshold of 300 yen in income. In the initial year, the total number of income tax filers amounted to 0.3 percent of the total Japanese population. As a comparison, the rates for the U.S. PIT in 1913 ranged from 1 to 7 percent and the personal exemption was 3,000 dollars; the total number of U.S. tax filers at the time amounted to 0.5 percent of the total 
U.S. population. Before the 1899 reform, dividend income in Japan was taxable but otherwise corporate income escaped taxation, which was excluded primarily to protect the nascent industrial sector. We consider local tax consequences later in this section.

In theory, a firm weighs benefits and costs to decide on incorporation (Gordon and MacKie-Mason 1994; Liu 2014). Non-tax benefits include limited liability status for investors; the ability to raise external funds on equity markets; and continuity of the organizational structure in events such as an owner's death. Non-tax costs include legal fees arising from a complex organizational structure; accounting and disclosure regulations; and (higher) statutory capital requirements. For instance, if a purchase of a government-owned factory requires a large initial deposit, then non-tax benefits would dominate the incorporation decision regardless of tax considerations and entrepreneurs would incorporate to finance the project jointly. On the other hand, if family members can self-finance a project with their own resources, non-tax costs like increased disclosure and third-party intervention may discourage the family firm from incorporating, such as with some zaibatsu during this period (Morikawa 1992, p. 94). The latter type of firms however may find it advantageous to incorporate if tax savings from incorporating is sufficiently large. Intuitively, the theory predicts that tax savings sway decisions of firms for whom the net non-tax benefits of incorporation are close to zero, or "firms at the margin."

The U.S. context in the early twentieth century is again illustrative, where the costs of being incorporated were both higher than the benefits and more variable. On average, one dollar of corporate income was taxed six cents more than non-corporate income over 1909-1919, but ranged up to 20 cents higher after accounting for double taxation and state taxes (Liu 2014). In our setting, assuming that a corporation retained all earnings and its owners would have faced the top marginal tax rate if the firm was not incorporated, one hundred yen of corporate income is taxed three yen less than non-corporate income with much lower variation in tax incentives.

Meiji Japanese policymakers were aware of tax avoidance opportunities through incorporation, as recorded in parliamentary meetings, but opinions differed on whether loopholes would be exploited (Orii and Yamamoto 1990, pp. 77-78). One consideration was that many prominent entrepreneurs during the Meiji Period (1868-1912) were former samurai, although their share and wealth varied considerably by region and over time (Abe 2007). Members of this warrior class were issued government bonds in exchange for their hereditary stipends and subsequently used 


\section{Taxes and the Choice of Organizational Form in Japan 445}

the bonds as financial capital. This was motivated in part by the falling real value of these bonds, so many ex-samurai used them as collateral for firm capitalization in nominal terms. The prominence of former samurai among early entrepreneurs contributed to a trusting view of their behavior. For example, in the minutes of a senate meeting held on 22 February 1887, a member of a council argued that owners of businesses were typically noblemen who would not avoid taxes in "petty" ways (Orii and Yamamoto 1990). Another councilman forcefully pointed that it is unfair to treat businesses run by one person versus multiple people differentially.

An additional issue is the role of local taxes. At the beginning of the Meiji Period, local administrations inherited taxes and levies from the previous regime, which varied considerably. Concerns about uneven tax practices, and the sheer number of various levies, led the central government to coordinate prefecture-level taxes by standardizing regulation. One of the main rules, set in 1878, was the establishment of the Business Operations Tax (Eigyo zei) that initially was based on external characteristics like sales and levied mainly on merchants. This 1878 rule set an upper limit on the annual levy by business category. For example, the maximum annual levy for a company (kaisha) and wholesalers was 15 yen while that for retailers was five yen (Hayashi 1965). Thus, except for wholesalers and retailers who were taxed regardless, incorporation triggered a tax liability and therefore was disadvantageous. An amendment in 1880 , however, abolished this categorization and set a uniform maximum tax at 15 yen, and made manufacturing plants liable for taxation regardless of organizational form. Further, another amendment two years later abolished the distinctions between commerce and manufacturing and between sole proprietorship and corporation, respectively. By 1887, the tax disincentives for incorporation under the Business Operations Tax had been removed. ${ }^{4}$

The enforcement and administration of the early PIT also differed from Japan's modern tax system administered by tax specialists. During the Meiji Period, the central government delegated the responsibility of assessment and collection to administrators in the counties (gun). For each county, a tax commission comprising personnel elected in a local election assessed incomes and liaised between the county administration and local taxpayers. Since the suffrage at the local election depended on the amount of tax payments, there often was overlap between the tax commission and elected officers in local assemblies. The tax committee

\footnotetext{
${ }^{4}$ See Maruyama (1985) for discussion on local exemptions, incentives, and tax reforms.
} 
checked tax returns submitted by taxpayers and also conducted investigations with the assistance of county administrators.

The early assessment appeared idiosyncratic. It was not until around 1893 that the administration started to "predict" income on the basis of observable features like land price, outstanding loans, and local taxes, and compared them with declared figures (Orii and Yamamoto 1990, pp. 334-35). The National Tax Agency gradually took over responsibilities: the government established regional tax offices that took charge of tax collection in 1896, and the local offices assessed corporate income (but not personal income) from 1899. The enforcement regime would have varied considerably given this new administrative apparatus: The number of personal tax payers increased by 75 percent in one year over 1898-1899 despite the same personal exemption amount (Tōyō Keizai Shinpōsha 1975, table 730). Given those weaknesses in administration and enforcement, firms may have found it easier to substitute tax avoidance with tax evasion. Whether firms actually responded to tax incentives by incorporating businesses is, however, an empirical question that we test in our analysis.

\section{CORPORATIONS IN THE MEIJI PERIOD}

Japan at the start of the Meiji Period (1868-1912) retained the previous Tokugawa era's flourishing commercial economy, a well-developed customary law that allowed merchants to issue promissory notes, and family-oriented joint ventures (Miyamoto 1990; Nakamura 2010). To promote industrialization, the Meiji government published textbooks on incorporation, coordinated merchants to form trading companies in 1869, and organized national banks as joint-stock corporations. Absent formal and standardized regulation in most sectors before the 1890s, the various prefectural governments followed the processes and administration of incorporation on the references published by the central government, but many features like investor liability and shareholder voting rights were not well understood. For firms outside finance and key industries like construction or transport, incorporation often amounted to notifying a local authority (Nakamura 2010).

Given the lack of national regulation, prefectural governments stepped up regulation starting in the mid-1880s. Osaka prefecture, for example, required new as well as existing corporations to submit corporate charters, starting from February 1886. Fraud, in which a swindler collected funds from investors and fled, was common. The urgent need for order led to a drafting of the national Commercial Code (Shōhō), but complaints 


\section{Taxes and the Choice of Organizational Form in Japan 447}

delayed implementation until 1899, except for sections including corporation acts that were promulgated in January 1893.

The Commercial Code of 1893 defined three types of corporation, and outlined requirements for organizing a corporation (Yoshida 1998; Nicholas 2015). First, investors in joint-stock corporations (kabushiki gaisha) enjoyed limited liability, but needed to obtain approval on articles of incorporation and also an establishment license. Creditors to joint-stock corporations could request disclosure of balance sheets. Limited partnerships (gōshi gaisha) consisted of investors with partners with limited and unlimited liability while partnerships (gomei gaisha) consisted of partners with unlimited liability. While the translations of the Japanese words suggest that these types of firms were pass-through entities similar to those found in other countries, they were in fact corporations and thus not taxed under PIT. Requirements for founding the latter two types were fewer, with a company able to register its establishment without a license. The 1893 code also increased regulatory stringency. For example, a director of a limited partnership was liable to cover losses within two years of his departure. In sum, except for the regulated sectors, "corporation" was loosely defined until 1893, when the partial implementation of the Commercial Code finally established explicit guidelines.

\section{FIRM GENEALOGICAL DATA}

The main data source is the collection of corporate genealogies edited by Yagura and Ikushima (1986). Companies in this collection consist of 1,089 corporations traded at the first tier of the Tokyo Stock Exchange in 1984. Yagura and Ikushima drew genealogical charts based on "autobiographical" accounts of corporate histories, which include some of the oldest firm-level information available for Japan. The main components of a genealogical chart are nodes and branches. We adopt these terms, node and branch, from the standard description of a tree diagram. Each node contains information about a unit, such as a date of establishment, ownership type, industry classification, and geographical location. To avoid ambiguity, a unit refers to a business entity that appears on a genealogical chart. A unit does not need be a "firm" in the conventional sense of the word since a firm experiencing a name change appears on a chart as two distinct nodes. We will however use the words, unit and firm, interchangeably. A branch indicates an organizational transformation from a lower (older) unit to a higher (younger) unit, such as an incorporation of a sole proprietor, but also includes other transformations such as 
mergers and acquisitions. We provide a graphical example in the Online Appendix.

From the genealogical charts, John P. Tang $(2011,2013)$ coded information on nodes/units, so the dataset allows us to observe various organizational forms throughout the Meiji Period, including sole proprietorship (kojin kigyō), joint-stock corporation (kabushiki gaisha), limited partnership (gōshi gaisha), partnership (gōmei gaisha), limited liability company (yügen gaisha), mutual company (sougo gaisha), anonymous partnership (tokumei kumiai), and government corporation (seifu kigyō). Other sources of data on corporation types become available only after 1893, following the partial implementation of the Commercial Code, and thus post-date the introduction of the PIT (Nicholas 2015). We analyze a subset of Tang's $(2011,2013)$ dataset, which contains 2,597 firms by the end of the Meiji Period (1868-1912) and is structured as an unbalanced panel of firms with 35,363 firm-year observations. ${ }^{5}$ This dataset contains essential information for investigating the choice of organizational forms. Also, since a genealogical chart is a summary of organizational transformations, the dataset does not contain financial information. We describe further details on the coding of charts in the Online Appendix.

Using these data presents both some advantages and challenges. The key attraction of the genealogical data is their systematic coverage of firm-level observations, including information on organizational form, for a period when aggregate data by organizational forms do not exist. The genealogies also record name changes, including those due to changes in organizational forms, and cover the period when these forms were first actively adopted in the country. Perhaps surprisingly, the genealogical data seem to track growth of firms in the economy. The Pearson's correlation coefficient for the number of non-bank corporations in the genealogies and the estimated number of non-bank corporations for the national economy over $1899-1912$ is 0.97 and is statistically significant at the 1 percent level. The estimated number of non-bank corporations is the number of Type 1 income taxpayers, which serves as a proxy for the population of corporations minus the number of banking establishments (Tōyō Keizai Shinpōsha 1975; Japanese Bankers Association 2012). Moreover, the correlation coefficient for the number of all firms with real GDP over $1875-1912$ is 0.93 and is also significant at 1 percent (Japan Statistical Association 1987; Nakazawa 2001).

\footnotetext{
${ }^{5}$ It should be pointed out that this dataset does not contain information on branches, or organizational transformations, which were not necessary in the studies by Tang $(2011,2013)$. Information on whether a node is terminal or has a lower connecting node would have provided an opportunity for further analyses, but we are restricted from doing so with the present dataset.
} 


\section{Taxes and the Choice of Organizational Form in Japan 449}

A limitation to the data is that the sample of firms from these genealogies is a non-random subset of the population of businesses that existed at the time, and thus may bias inference. As time approaches 1984, the number of firms approaches 1,089 by construction and the share of corporations becomes unitary. Consequently, we would be reluctant to draw inference from a sample close to the time when the historians constructed the genealogies out of concern for this mechanical selection. The 1880 to 1892 sample used in our analysis, however, predates the construction of the genealogies by a century and thus selection into incorporation should not be an issue. This is corroborated by the increase in firm numbers that we observe in our sample, which contrasts with the decline in total number of firms over the entire period ending in 1987. Furthermore, the genealogies include not only those whose ultimate descendent survived and prospered, but also bankrupt firms who sold capital assets and ancestors of firms taken over in mergers (Tang 2011). The inclusion of these firms mitigates firm survivorship bias as well as increases the number of observations.

Another feature of the data is that the subject companies in the genealogies are firms successful enough to become first tier public corporations, which entails more rigorous listing requirements. Our sample contains the largest companies from the period as documented elsewhere (Fruin 1994, p. 329). Indeed, the incorporation rate gauged from tax statistics from 1899 is 1.3 percent, while that from our sample (excluding banks) is more than 60 percent in that year, indicating that our sample predominantly draws from the formal sector. ${ }^{6}$ If initial capital affects survival probabilities, joint-stock corporations, which are typically larger in size, would dominate the sample over time. If so, the corporate share would increase over time even without any tax incentives, though the inclusion of discontinued firms mitigates over-sampling of successful firms to some extent. The effects of this sample selection through survivorship would be gradual, however, and our identification strategy relies on an abrupt change at a point in time. In the empirical analysis, we control for this possible influence by including a trend term in the regression.

The genealogies also include major multi-sector conglomerates (zaibatsu) such as Mitsui, Sumitomo, and Mitsubishi, which emerged

\footnotetext{
${ }^{6}$ The number of taxpayers filing Type 1 income $(6,133)$ divided by Business Operations Tax filers in 1899 (475,917) (Tōyōo Keizai Shinpōsha 1975, Table 728, 730). Small businesses, such as second-hand cloth shops, pawnshops and inns, as well as large businesses, such as banks, were liable for the Business Operations Tax. Tax records from Nagano Prefecture in 1891 show, for example, rich farmers conducted sericulture and money lending as sole proprietors (Orii and Yamamoto 1990).
} 
before or during the Meiji Period and remain important firms today (Abe 2007; Tang 2011). Enterprises affiliated with these firms are listed in the genealogies of zaibatsu, which were originally owned and controlled by a family or kinship network, and possibly other genealogies if they were independent at one point. It should be noted that decisions undertaken in firms under the umbrella of a zaibatsu would be influenced by the owning family, and thus it is possible that incorporation decisions may be correlated across zaibatsu firms through the family's decision making. The Mitsui zaibatsu's reorganization of its structure in 1909 is a case in point (Nakamura 2010). This possible inter-zaibatsu correlation in decision is unlikely to affect the results, however, because the majority of sample firms are independent of zaibatsu. Also, any inter-zaibatsu correlation would be a small component of unexplained variations in the empirical models.

Lastly, and most relevant to the research question, the sample of large formal-sector firms likely understates tax effects. Previous studies indicate that the tax motive affects smaller firms, whose decisions are at the margin of incorporation, more than larger firms. Li Liu (2014) finds corporate shares of employment respond less than those of firm count. Similarly, Judith Freedman and Claire Crawford (2010) document that incorporation rates increased among smaller firms but not larger firms in the United Kingdom's experience with a 0 percent starting rate. Thus, results based on a sample of genealogies of large corporations would provide a lower bound on any tax effect and understate the impacts in the population.

To prepare the dataset for analysis, we drop banks given their separate regulatory regime. ${ }^{7} \mathrm{We}$ exclude government corporations, which may not have been profit-maximizing. We omit anonymous partners since they are pass-through entities. There are no mutual companies between 1880 and 1892 , so the sample consists of sole proprietors, partnerships, limited partnerships, limited liability corporations, and joint-stock corporations. Of the remaining organizational types, joint-stock corporations are on average much larger than other types of corporations. The average size of paid-in capital of joint-stock corporations in 1895 is three times larger than that of limited partnerships and 11 times larger than that of general partnerships. Theory suggests that tax incentives affect firms at the margin of incorporation (Gordon and MacKie-Mason, 1994). Non-tax factors, such

\footnotetext{
${ }^{7}$ The banking regulation affected banks' formation and determined their organizational forms. The National Bank Act (NBA) of 1872 established a decentralized national banking system similar to that in the United States at the time, with chartered national banks operating under a fractional reserve system and issuing gold-convertible notes (Tang 2013).
} 


\section{Taxes and the Choice of Organizational Form in Japan 451}

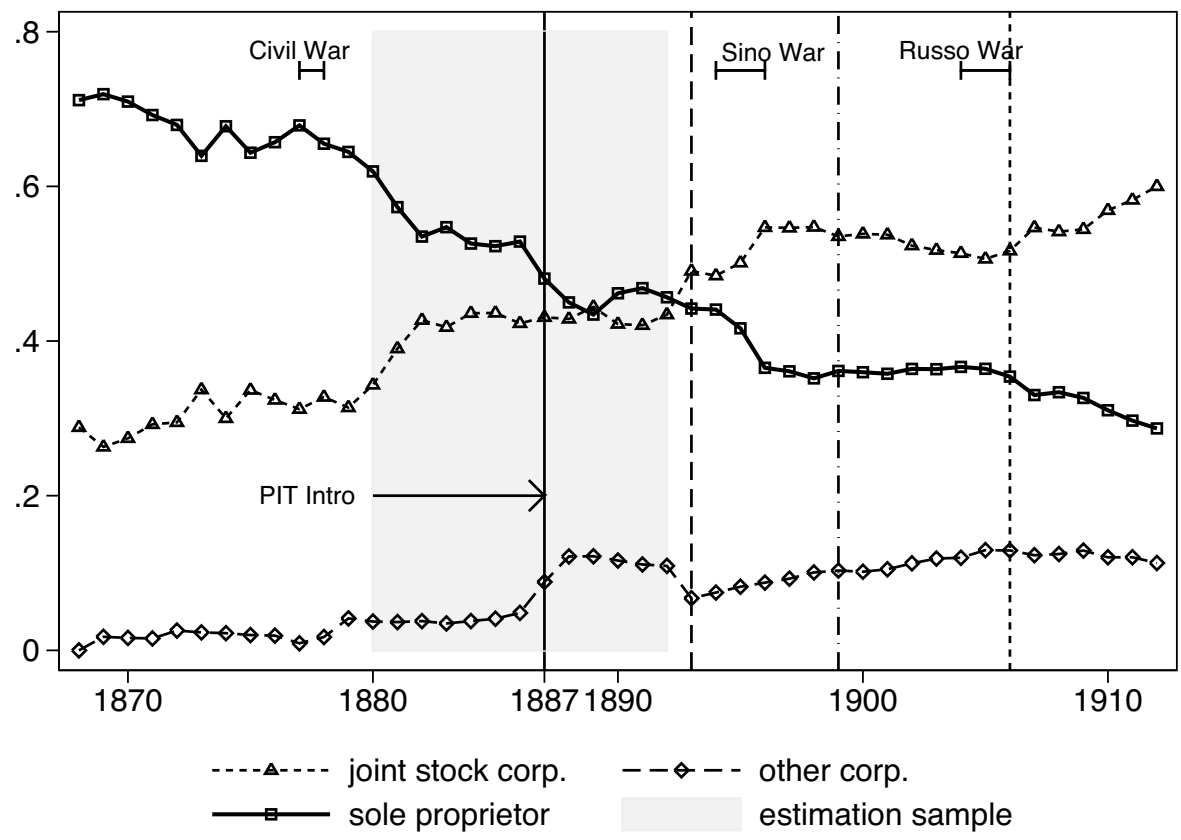

FIGURE 1

SHARES OF FIRMS BY ORGANIZATIONAL TYPES: ALL REGIONS

Note: The Civil War, First Sino-Japanese War, and Russo-Japanese War is for 1877.2-9, 1894.81895.4, and 1904.2-1905.9, respectively. The solid vertical line indicates the introduction of PIT. The dotted vertical lines indicate the timing of other major reforms: the partial implementation of the Commercial Code in 1893, Tax Reform of 1899, and a permanent extension of war taxes in 1906.

Source: The sample of genealogical firms excluding banks. See text for more details.

as the benefit of limited liability for investors, would likely dominate the choice of organizational form of a modern textile factory, for example, while a medium-size family business may not find a clear advantage in incorporation. We therefore treat joint-stock corporations as one category, and combine partnership, limited partnership, and limited liability corporations into a separate category, referred to as "other corporations."

Figure 1 provides a preliminary examination and shows the share of sole proprietors, joint-stock corporations, and other corporations for the entire Meiji Period. The solid vertical line indicates the introduction of PIT. The dotted vertical lines indicate the timing of other major reforms such as the partial implementation of the Commercial Code in 1893, Tax Reform of 1899, and a permanent extension of war taxes in 1906. Also indicated are various wars: the Civil War (February-September 1877), the First Sino-Japanese War (August 1894-April 1895), and the RussoJapanese War (February 1904-May 1905). 
The sample consists predominantly of sole proprietors at the beginning of the Meiji Period. The corporate share increases gradually throughout the period, and by the end of the Meiji, the share of sole proprietors is about a third of the sample. This broad trend is consistent with the rapid industrialization that took place particularly since the 1890s. In 1887, the share of other corporations jumps by 4 percentage points while the share of sole proprietors falls by 4.8 percentage points. A rise in limited liability companies accounts entirely for this increase in the share of other corporations in 1887. In contrast, we do not see visible changes for joint-stock corporations around the time. These patterns are consistent with the conjecture that the PIT induced sole proprietors to incorporate into simpler corporate forms.

Upon the partial implementation of the Commercial Code in 1893, the share of joint-stock corporations jumped while the share of other corporations fell abruptly. This shift suggests that the Commercial Code affected the choice of organizational forms within the corporate sector. The Tax Reform of 1899 does not appear to have had a large influence on the choice of organizational forms, despite the introduction of the 2.5 percent tax on corporate income. As Table 1 shows, the top marginal rate on personal income also increased from 3 to 5 percent, countering the disincentives to incorporate. The lack of a clear response at the aggregate level may be due to these countering tax incentives. Temporary war taxes, implemented during the Russo-Japanese War, increased the progressivity of the PIT and applied the progressive rate to income earned by partnerships, limited partnerships, and joint-stock corporations with 20 or fewer shareholders. Since its permanent extension in 1906, the share of jointstock corporations increased while that of sole proprietorship fell, in line with the tax minimization motives. Anecdotal evidence from Mitsui records indicates that the permanent extension motivated the company's organizational overhaul in 1909 (Matsumoto 1979).

In designing a quasi-experiment, we limit the sample period to 1880 1892 for the following reasons. First, this period keeps the regulatory environment relatively homogenous across the pre- and post-PIT samples. Only at the beginning of the 1880 s were the concepts of limited liability and joint-stock companies more familiar to the Japanese, culminating in the 1893 Commercial Code, with an enforcement regime that also became more sophisticated over time (Morikawa 1992, p. 27). Second, the sample spans a period of relative political stability and falls between the Civil War and First Sino-Japanese War. The rise in corporate share after the latter war may reflect an economic boom that followed. We chose the end year given the partial implementation of the 1893 Commercial 
TABLE 2

SUMMARY STATISTICS

\begin{tabular}{lccccc}
\hline \hline Variables & Mean & $\begin{array}{c}\text { Standard } \\
\text { Deviation }\end{array}$ & Minimum & Maximum & $\mathrm{N}$ \\
\hline Joint-stock corporation (jsc) $=1$ & 0.42 & 0.49 & 0 & 1 & 3,203 \\
Sole proprietor (sp) $=1$ & 0.50 & 0.50 & 0 & 1 & 3,203 \\
Other corporation (oc) $=1$ & 0.08 & 0.27 & 0 & 1 & 3,203 \\
Stock index growth & -0.02 & 0.17 & -0.40 & 0.46 & 3,203 \\
Real IR index & 0.36 & 0.14 & 0.26 & 0.75 & 3,203 \\
GDP growth & 0.04 & 0.08 & -0.06 & 0.17 & 3,203 \\
Industry growth & 0.09 & 0.16 & -0.13 & 3.00 & 3,203 \\
Age (/100) & 0.34 & 0.59 & 0.01 & 3.07 & 3,203 \\
\hline
\end{tabular}

Note: This table is based on authors' computation using the firm-year observations covering 1880-1892 constructed from the genealogical charts in Yagura and Ikushima (1986). The sample excludes banks, government corporations, and antonymous partners.

Source: See Appendix Table 1.

Code. Since the choice of 1892 limits the number of post-reform years to six, we chose the beginning year of 1880 to keep the length of the prereform period comparable (seven years). The base sample employed in the analyses consists of 3,203 firm-year observations from 1880-1892 on 451 firms. Table 2 provides summary statistics of variables employed in regression analyses, and Appendix Table 1 provides detailed information on sources.

\section{METHODOLOGICAL APPROACH AND BASELINE RESULTS}

To estimate the effects of tax incentives, we utilize the introduction of PIT in 1887 as a quasi-experiment. Since the data suggest that the PIT encouraged the formation of "other corporations," we pool firm-year observations for sole proprietors and other corporations from 1880-1892 and examine the likelihood of incorporation with the following linear probability model:

$$
O C_{i t}=\alpha_{0}+\alpha_{1} P I T_{t}+x_{i t}^{\prime} \beta+\lambda_{j} t+\mu_{k}+u_{i t}
$$

where $O C_{i t}$ is an indicator for firm $i$ from time period $t$ being other corporations (partners, limited partners, and limited liability corporations). $P I T_{t}$ is an indicator for time period at and after 1887. The coefficient $\alpha_{1}$ captures the difference in the probabilities of incorporation before and after the reform, conditional on the control variables. 
The identification of tax effects relies on the time variation in tax incentives since PIT was at the national level. Since business conditions can confound the influence of taxes, we consider several macroeconomic controls $x_{i t}$. In the early $1880 \mathrm{~s}$, a contractionary fiscal policy induced a severe deflation, known as the Matsukata Deflation, as a response to loose monetary policy in the aftermath of the 1877 civil war. The economy was still recovering when the government introduced PIT. To account for possible business cycle effects, we control for the real gross domestic product (GDP) growth rate. The impact of the business cycle would have differed by industries, but we can approximate industry growth rates using growth in firm counts by sector from the genealogical data since these series are highly correlated (Tang 2013). We also include the growth rate of the Tokyo stock price index, which should be exogenous to the tax changes. This is because joint-stock corporations in railways, whose sizes exceeded the financial resources of the wealthiest Japanese families (Morikawa 1992, p. 27), primarily determined the total size of market capitalization. While publicly-traded companies were few in number, particularly in the first years following the foundation of the Tokyo and Osaka stock exchanges in 1878, they accounted for $30-40$ percent of the total capital of joint-stock corporations. Thus, the stock index captures the broad trend in the formal sector. ${ }^{8}$ We control for real interest rates to account for access to external finance.

An increase in incorporation rates over the Meiji Period, shown in Figure 1, likely reflects technological change. Table 3 presents changes in the shares of organizational types by industry before and after the 1887 reform. Notably, the textile industry, which underwent a large transformation by the introduction of Western-style factories, exhibits a large decline in the share of sole proprietors across the periods. This is consistent with the increasing scale and agglomeration economies of a more integrated national market and rapid diffusion of foreign technologies (Tang 2014, 2016). Some of these increases in incorporation rates may also be attributable to the survivorship bias or mechanical increase as discussed earlier. We therefore also include industry-specific linear time trends $\lambda_{j}$ to control for technological change and possible influences from the dataset construction. ${ }^{9}$

In addition, $x_{i t}$ includes a vector of explanatory variables: region dummies, industry dummies (12 industries), and the number of years

\footnotetext{
${ }^{8}$ In 1878, 1885, and 1915, there were 4, 24, and 151 firms traded on the stock market, respectively (Okazaki, Hamao, and Hoshi 2005).

${ }^{9}$ Estimates using a quadratic time trend were also consistent with the linear baseline and other model shown in the tables.
} 
TABLE 3

THE SHARE OF ORGANIZATIONAL TYPE BY INDUSTRIES AND TAX REGIMES

\begin{tabular}{|c|c|c|c|c|c|c|c|c|c|c|c|c|}
\hline \multirow[b]{2}{*}{ Industry } & \multicolumn{4}{|c|}{ Sole Proprietor } & \multicolumn{4}{|c|}{ Other Corporate } & \multicolumn{4}{|c|}{ Joint-Stock Corporations } \\
\hline & Before & After & Total & Change & Before & After & Total & Change & Before & After & Total & Change \\
\hline Primary & 90.0 & 86.1 & 87.8 & -3.9 & 0.0 & 4.0 & 2.2 & 4.0 & 10.0 & 9.9 & 10.0 & -0.1 \\
\hline Retail & 87.2 & 85.0 & 86.0 & -2.2 & 0.0 & 4.9 & 2.6 & 4.9 & 12.8 & 10.1 & 11.4 & -2.7 \\
\hline Metal & 81.1 & 61.9 & 69.0 & -19.2 & 0.0 & 0.0 & 0.0 & 0.0 & 18.9 & 38.1 & 31.0 & 19.2 \\
\hline Machinery & 65.1 & 65.7 & 65.4 & 0.6 & 4.8 & 15.7 & 11.0 & 10.9 & 30.1 & 18.5 & 23.6 & -11.6 \\
\hline Chemical & 73.4 & 58.8 & 64.0 & -14.6 & 10.9 & 9.6 & 10.1 & -1.3 & 15.6 & 31.6 & 25.8 & 16.0 \\
\hline Ceramic & 69.2 & 52.5 & 59.0 & -16.7 & 3.1 & 12.9 & 9.0 & 9.8 & 27.7 & 34.7 & 31.9 & 7.0 \\
\hline Food \& beverage & 50.0 & 42.2 & 45.5 & -7.8 & 4.5 & 10.0 & 7.7 & 5.5 & 45.5 & 47.8 & 46.8 & 2.3 \\
\hline Textile & 53.0 & 21.3 & 30.8 & -31.7 & 5.2 & 19.4 & 15.1 & 14.2 & 41.7 & 59.3 & 54.0 & 17.6 \\
\hline Wood products & 30.2 & 23.2 & 25.7 & -7.0 & 15.1 & 34.3 & 27.6 & 19.2 & 54.7 & 42.4 & 46.7 & -12.3 \\
\hline Transportation & 27.2 & 17.8 & 21.6 & -9.4 & 2.9 & 11.8 & 8.2 & 8.9 & 69.9 & 70.4 & 70.2 & 0.5 \\
\hline Other & 17.4 & 19.1 & 18.4 & 1.7 & 0.0 & 5.9 & 3.2 & 5.9 & 82.6 & 75.0 & 78.4 & -7.6 \\
\hline Finance & 13.5 & 17.4 & 15.5 & 3.9 & 10.8 & 10.4 & 10.6 & -0.4 & 75.7 & 72.1 & 73.8 & -3.6 \\
\hline Total & 54.5 & 45.8 & 49.5 & -8.7 & 3.9 & 11.2 & 8.1 & 7.3 & 41.5 & 43.0 & 42.4 & 1.5 \\
\hline \multicolumn{13}{|c|}{$\begin{array}{l}\text { Note: This table presents percentages of organizational types for a given time period }(1880-1886,1887-1892) \text { and industry. The data source is the firm-yea } \\
\text { observations constructed from the the genealogical charts in Yagura and Ikushima (1986). The bottom row ("Total") presents shares aggregated over industrie } \\
\text { for a given time period. The columns titled "Total" refers to shares aggregated over time periods. The columns titled "Change" refers to changes in shares fron } \\
\text { the before period to the after period for each industry. } \\
\text { Source: See Table } 2 \text {. }\end{array}$} \\
\hline
\end{tabular}


since the founding of the oldest firm in a genealogy to which firm $i$ belongs (genealogy age). We consider specifications with and without the genealogy fixed effect $\mu_{k}$. Reorganizations typically took place within an industry, so firms listed on a given genealogy tended to be in the same industry, which we corroborate with Herfindahl-Hirschman Index (HHI) calculations..$^{10}$ A genealogy fixed effect should capture the characteristics of narrow industry not accounted for by the industry dummies. We allow for a heteroskedastic error term with White's correction.

Columns $1-3$ in Table 4 show estimates from the linear probability model using the pooled firm-year sample. The specification in Column 1 includes a full set of macroeconomic controls, an industry-specific time trend, and firm-level controls. The model fit seems reasonable: industrylevel trends, industry dummies, and regional dummies account for much of the explained variation. The coefficients on genealogy age and squared age are statistically significant. Their point estimates imply that a firm in an "older" genealogy tends to be a corporation, in line with the theory that businesses incorporate as they mature and their organizational structures become more complex.

Column 2 includes the dummy for the PIT introduction, which is statistically significant at the 1 percent level. Column 3 adds genealogy fixed effects, and shows that the coefficient on PIT is lower but is still statistically significant. This point estimate indicates that the share of incorporation increased by 5.5 percent for the sub-sample that excludes jointstock corporations. This translates to a 3.2 percent increase for the whole sample. ${ }^{11}$ The share of other corporations was 3.9 percent in the pre-PIT period, so the magnitude of the policy effect is economically significant. This overall result compares favorably with the existing literature of American tax policy on incorporation in the early twentieth century. That is, Austan Goolsbee (1998) examines aggregate U.S. data over 19001939, which span changes to federal income taxes. He finds statistically significant but negligible impacts. Liu (2014) examines a state panel dataset drawn from U.S. census data in the years 1909, 1914, and 1919, and finds a 1 percent increase in PIT leads to a 5.5 percent increase in the share of incorporated firms. ${ }^{12}$ The estimates from our study are thus

${ }^{10}$ We computed the HHI from the count of industry classification within genealogies using unbalanced panel of firms. The average $\mathrm{HHI}$ is above 0.9 whether we use all available observations (1870-1912), restrict the sample period (1880-1892), or drop genealogies with fewer than the median number of firms (11) during the sample period.

${ }^{11}$ That is, 0.055 times the share of firms other than joint-stock corporations in the pre-taxreform sample (0.585).

${ }^{12}$ For another line of taxation study, see Romer and Romer (2014). 


\section{Taxes and the Choice of Organizational Form in Japan 457}

TABLE 4

REGRESSION ANALYSIS: BASE SAMPLE

\begin{tabular}{|c|c|c|c|c|c|}
\hline \multirow{4}{*}{$\begin{array}{l}\text { Sample Estimator } \\
\text { Dependent Variable }\end{array}$} & (1) & (2) & (3) & (4) & (5) \\
\hline & \multicolumn{3}{|c|}{$\begin{array}{l}\text { Pooled (sp, oc) } \\
\text { LP }\end{array}$} & \multicolumn{2}{|c|}{$\begin{array}{l}\text { Pooled (all) } \\
\text { MNL }\end{array}$} \\
\hline & \multirow{2}{*}{\multicolumn{3}{|c|}{ Indicator for Other Corp. }} & \multicolumn{2}{|c|}{ Org. Type Categories } \\
\hline & & & & Other Corp. & Joint-Stock \\
\hline Dependent Variable Code & $\mathrm{oc}$ & $\mathrm{oc}$ & oc & $\mathrm{Oc}^{\mathrm{a}}$ & $\mathrm{jsc}^{\mathrm{a}}$ \\
\hline PIT Introduction & & $\begin{array}{c}0.104^{* *} \\
(0.032)\end{array}$ & $\begin{array}{r}0.055^{* *} \\
(0.018)\end{array}$ & $\begin{array}{l}1.200^{* *} \\
(0.381)\end{array}$ & $\begin{array}{l}0.108 \\
(0.214)\end{array}$ \\
\hline GDP growth & $\begin{array}{c}0.020 \\
(0.134)\end{array}$ & $\begin{array}{c}0.011 \\
(0.134)\end{array}$ & $\begin{array}{l}-0.011 \\
(0.074)\end{array}$ & $\begin{array}{c}0.294 \\
(1.145)\end{array}$ & $\begin{array}{l}-0.012 \\
(0.787)\end{array}$ \\
\hline Industry growth & $\begin{array}{c}0.028 \\
(0.047)\end{array}$ & $\begin{array}{l}-0.000 \\
(0.046)\end{array}$ & $\begin{array}{l}-0.013 \\
(0.031)\end{array}$ & $\begin{array}{l}-0.091 \\
(0.609)\end{array}$ & $\begin{array}{c}0.288 \\
(0.339)\end{array}$ \\
\hline Stock index growth & $\begin{array}{l}-0.036 \\
(0.051)\end{array}$ & $\begin{array}{c}0.028 \\
(0.053)\end{array}$ & $\begin{array}{l}-0.001 \\
(0.030)\end{array}$ & $\begin{array}{c}0.532 \\
(0.734)\end{array}$ & $\begin{array}{l}-0.066 \\
(0.380)\end{array}$ \\
\hline IR index & $\begin{array}{l}-0.019 \\
(0.087)\end{array}$ & $\begin{array}{l}-0.031 \\
(0.088)\end{array}$ & $\begin{array}{c}0.030 \\
(0.054)\end{array}$ & $\begin{array}{l}-1.471 \\
(1.166)\end{array}$ & $\begin{array}{l}-0.810 \\
(0.666)\end{array}$ \\
\hline Age/100 & $\begin{array}{r}-0.057^{*} \\
(0.025)\end{array}$ & $\begin{array}{c}-0.058^{*} \\
(0.025)\end{array}$ & $\begin{array}{c}0.029 \\
(0.107)\end{array}$ & $\begin{array}{c}-3.153^{* *} \\
(0.552)\end{array}$ & $\begin{array}{c}-1.533^{* *} \\
(0.311)\end{array}$ \\
\hline$(\text { Age } / 100)^{2}$ & $\begin{array}{l}0.024 * \\
(0.009)\end{array}$ & $\begin{array}{l}0.024^{*} \\
(0.009)\end{array}$ & $\begin{array}{c}-0.143 * * \\
(0.052)\end{array}$ & $\begin{array}{l}1.273^{* *} \\
(0.197)\end{array}$ & $\begin{array}{c}0.664 * * \\
(0.129)\end{array}$ \\
\hline Time & $\begin{array}{l}0.020^{*} \\
(0.008)\end{array}$ & $\begin{array}{c}0.006 \\
(0.010)\end{array}$ & $\begin{array}{l}-0.002 \\
(0.004)\end{array}$ & $\begin{array}{c}0.086 \\
(0.103)\end{array}$ & $\begin{array}{c}0.074 \\
(0.061)\end{array}$ \\
\hline Constant & $\begin{array}{r}-0.385^{*} \\
(0.169)\end{array}$ & $\begin{array}{l}-0.163 \\
(0.191)\end{array}$ & $\begin{array}{c}-0.357 * * \\
(0.133)\end{array}$ & $\begin{array}{c}-6.461 * * \\
(2.378)\end{array}$ & $\begin{array}{c}-0.385^{*} \\
(1.328)\end{array}$ \\
\hline Fixed effects & No & No & Yes $^{\mathrm{b}}$ & & \\
\hline $\begin{array}{l}\text { PIT marginal effects } \\
\text { (Unit) }\end{array}$ & & $\begin{array}{c}10.4 \\
\text { (percent pt) }\end{array}$ & $\begin{array}{c}5.5 \\
\text { (percent pt) }\end{array}$ & $\begin{array}{c}6.5 \\
\text { (percent pt) }\end{array}$ & $\begin{array}{c}2.0 \\
\text { (percent pt) }\end{array}$ \\
\hline Observations & 1,846 & 1,846 & 1,846 & & \\
\hline R-squared ${ }^{c}$ & 0.228 & 0.232 & 0.753 & & \\
\hline LL & - & - & - & & \\
\hline LL_0 & - & - & - & & \\
\hline
\end{tabular}

Note: This table presents regression analysis on the base sample. "sp," "oc," and "jsc" stands for sole proprietors, other corporations, and joint-stock corporations, respectively. Columns (1)-(3) presents OLS estimates on the indicator for other corporations (oc) in a sample that excludes joint-stock corporations. Columns (4)-(5) present multinomial logit (MNL) estimates (the base category is $\mathrm{sp}$ ). All specifications include industry-specific time trends, industry dummies, and region dummies. Robust standard errors are in parentheses.

${ }^{\mathrm{a}}$ Outcome variables.

${ }^{\mathrm{b}}$ Genealogy dummies.

${ }^{\mathrm{c}}$ Adjusted R-squared for (1)-(3); pseudo R-squared for (4)-(5).

$* * p<0.01, * p<0.05,+p<0.1$.

Source: See Table 2. 
between those of earlier studies, and can also be interpreted as a lower bound.

The coefficients on genealogy age and its square change signs after the inclusion of the genealogy fixed effect. The sources of variation in the age variable include differences across genealogies at a given point in time (cross-sectional variation) and variations within a genealogy (timeseries variation) of up to 13 years, the sample period length. Since the model in Column 3 controls for genealogy fixed effects, thus absorbing the cross-sectional variation, the time-series variation identifies the coefficients on the age variables in this specification. The implied overall effect of age in Column 3 is small for younger genealogies, while for very old genealogies the probability of firms being other corporations decreases over time. Since acquisitions were one means by which firms grew, a likely scenario is that more independent firms appeared in the period. These smaller firms, which started off as sole proprietors, then became acquisition targets of older genealogy firms.

\section{ROBUSTNESS CHECKS}

The baseline estimation excluded joint-stock corporations to focus on the choice between a sole proprietorship and a non-joint-stock corporation. To see if this estimation strategy affects the result, we estimate a multinomial logit model on a sample that includes joint-stock corporations, following Jeffrey Wooldridge (2010):

$$
P\left(y_{i t}=m \mid z_{i t}\right)=\exp \left(z^{\prime}{ }_{i t} \beta_{m}\right) /\left[1+\sum_{h=2}^{3} \exp \left(z^{\prime}{ }_{i t} \beta_{h}\right)\right],
$$

where $m$ indicates three outcome categories: (1) sole proprietorships, (2) other corporations, and (3) joint-stock corporations, with sole proprietorships as the base category in the estimation. The vector $z$ includes PIT and a set of control variables, including $x$ from equation 1 and industryspecific linear time trends. As before, we allow for heteroskedastic errors.

Columns $4-5$ in Table 4 present the results. The coefficient on $P I T_{t}$ is significant at the 1 percent level for other corporations but not for joint-stock corporations. To interpret the magnitude, we compute the difference in predicted probabilities. The result indicates that observations from the post-reform period are 6.5 percentage points more likely to become "other corporations" than observations from the pre-reform period. This is slightly higher than the unconditional differences in probabilities between 1886 and 1887. In summary, the result is robust to the exclusion of joint-stock corporations. 
TABLE 5

FREQUENCY OF TYPE COUNTS WITHIN GENEALOGY-YEAR

\begin{tabular}{lccccccc}
\hline \hline Count & \multicolumn{2}{c}{ Sole Proprietor } & \multicolumn{2}{c}{ Other Corp. } & \multicolumn{2}{c}{ Joint-Stock Corp. } & Combined \\
\hline 0 & 600 & $(32.4)$ & 1,671 & $(90.2)$ & 1,154 & $(62.3)$ & 0 \\
1 & 1,087 & $(58.7)$ & 149 & $(8.0)$ & 401 & $(21.6)$ & 1,360 \\
2 & 140 & $(7.6)$ & 20 & $(1.1)$ & 145 & $(7.8)$ & 212 \\
3 & 25 & $(1.4)$ & 12 & $(0.7)$ & 82 & $(4.4)$ & 125 \\
4 & 1 & $(0.1)$ & 1 & $(0.1)$ & 35 & $(1.9)$ & 71 \\
5 & 0 & $(0.0)$ & 0 & $(0.0)$ & 29 & $(1.6)$ & 54 \\
6 & 0 & $(0.0)$ & 0 & $(0.0)$ & 1 & $(0.1)$ & 12 \\
$7+$ & 0 & $(0.0)$ & 0 & $(0.0)$ & 6 & $(0.4)$ & 19 \\
\hline
\end{tabular}

Note: Percent of column in parentheses.

Source: The sample is based on the panel of genealogies described in the text.

We also consider a panel regression analysis to account for unobservable characteristics. We first take each genealogy as a panel unit, and in a separate analysis use industry as an alternative panel unit. ${ }^{13}$ To construct genealogy-level panel data, we aggregate observations over genealogies and year after dropping any banks and government corporations from within those genealogies. We then retain genealogies with five or more observations and those that started up before the year 1887 . We also retain observations with year gaps.

We consider counts of each type of organization per genealogy-year, rather than shares, since the number of firms within a genealogy is typically small. Table 5 shows the tabulation by organizational types. The means of these counts are small; in particular, the range for sole proprietor and other corporation is between zero and four, with a large mass of zero outcomes across all the types. One modeling approach, common in the organizational form literature employing industry or state aggregate data, would be to take the share of an organizational type as a dependent variable (de Mooij and Nicodème 2008; Liu 2014). The shares of organizational type in our micro-level data take small numbers of discrete values and contain many zeroes. Count is therefore an outcome more suitable in a regression analysis. An estimator that explicitly models outcome variables taking positive integer values is the Poisson regression, as discussed by Wooldridge (2010). In modeling count data with a small mean outcome, the Poisson regression has an advantage over a

\footnotetext{
${ }^{13}$ We are unable to connect units appearing in genealogical charts to construct a panel dataset of firms absent information on branches as mentioned in the data source section and discussed further in the Online Appendix.
} 
linear regression in restricting predicted values to positive integers and in accounting for outcomes of zero. One drawback is that the estimates from this approach are not directly comparable with those from previous estimates.

To be able to include genealogy fixed effects, we employ the fixedeffects Poisson regression following Wooldridge (2010). We assume that the number of firms that takes a certain organizational type in a given genealogy at any point in time, conditional on observables and an unobserved fixed-component, follows a Poisson distribution:

$$
\begin{gathered}
f\left(\text { numtype }_{k t} \mid z_{k t}, c_{k}\right)=\exp \left[-c_{k} \exp \left(z^{\prime}{ }_{k t} \beta\right)\right] \\
\left\lfloor c_{k} \exp \left(z^{\prime}{ }_{k t} \beta\right)\right\rfloor^{\text {numtype }_{k t / \text { numtype }}{ }_{k t} !}
\end{gathered}
$$

where $f($.$) is a probability density function; k$ indexes genealogy. The outcome variable, numtype $_{k t}$, is the number of firms that take an organization type (sole proprietorship, other corporation, or joint-stock corporation) in genealogy $k$ at time $t$. The vector $z_{k t}$ includes $P I T_{t}$ and a vector of control variables from (2), excluding regional and industry dummies. The term $c_{k}$ accounts for time-invariant unobservable characteristics of genealogy $k$.

The genealogies differ in the number of firms at any given point of time. Naturally, differences in size affect the count of organizational types. We therefore consider incorporation rates by including the number of firms as an exposure variable with a unit coefficient. In estimation, we drop genealogies with all zero outcomes for a given organizational type, so the sample size varies by outcome analyzed. To control for industry output growth, each genealogy needs an industry classification. We counted the frequency of industry classifications within each genealogy over the sample period, and assigned the industry with the highest count. Industry counts are concentrated within genealogy, and this approach should provide a reasonable approximation. We cluster the standard errors within panel by genealogy.

Columns 1-3 of Table 6 show estimates from the fixed-effect Poisson regression on the count of firm type using the genealogy panel data. The coefficient on PIT $_{t}$ is statistically significant at the 5 percent level for sole proprietorship. The magnitude indicates that the number of sole proprietors fell by 6.8 percent per genealogy, or by 0.053 firms per genealogy. ${ }^{14}$ The coefficient on $P I T_{t}$ is significant at the 1 percent level for

\footnotetext{
${ }^{14}$ This is calculated using the sample average for $1880-1886(0.782)$ multiplied by 0.068 .
} 


\section{Taxes and the Choice of Organizational Form in Japan 461}

TABLE 6

REGRESSION ANALYSIS: PANEL DATA

\begin{tabular}{|c|c|c|c|c|c|c|}
\hline \multirow{4}{*}{$\begin{array}{l}\text { Sample Estimator } \\
\text { Dependent Variable }\end{array}$} & (1) & (2) & (3) & (4) & (5) & (6) \\
\hline & \multicolumn{3}{|c|}{$\begin{array}{c}\text { Genealogy Panel } \\
\text { FE Poisson }\end{array}$} & \multicolumn{3}{|c|}{$\begin{array}{l}\text { Industry Panel } \\
\text { FE }\end{array}$} \\
\hline & \multicolumn{3}{|c|}{ Count of Each Org. Type } & \multicolumn{3}{|c|}{ Share of Each Org. Type } \\
\hline & $\begin{array}{l}\text { Sole Prop. } \\
\text { numsp }\end{array}$ & $\begin{array}{l}\text { Other Corp. } \\
\text { numoc }\end{array}$ & $\begin{array}{l}\text { Joint Stock } \\
\text { numjsc }\end{array}$ & $\begin{array}{l}\text { Sole Prop. } \\
\text { sharesp }\end{array}$ & $\begin{array}{l}\text { Other Corp. } \\
\text { shareoc }\end{array}$ & $\begin{array}{l}\text { Joint Stock } \\
\text { sharejsc }\end{array}$ \\
\hline PIT Introduction & $\begin{array}{c}-0.068^{*} \\
(0.030)\end{array}$ & $\begin{array}{l}0.849^{* *} \\
(0.306)\end{array}$ & $\begin{array}{l}-0.027 \\
(0.039)\end{array}$ & $\begin{array}{l}-0.025 \\
(0.035)\end{array}$ & $\begin{array}{l}0.058 * * \\
(0.015)\end{array}$ & $\begin{array}{l}-0.033 \\
(0.027)\end{array}$ \\
\hline GDP growth & $\begin{array}{c}0.024 \\
(0.051)\end{array}$ & $\begin{array}{l}0.492 * \\
(0.242)\end{array}$ & $\begin{array}{c}0.034 \\
(0.075)\end{array}$ & $\begin{array}{l}-0.029 \\
(0.041)\end{array}$ & $\begin{array}{c}0.012 \\
(0.012)\end{array}$ & $\begin{array}{c}0.017 \\
(0.037)\end{array}$ \\
\hline Industry growth & $\begin{array}{c}0.011 \\
(0.028)\end{array}$ & $\begin{array}{l}-0.052 \\
(0.229)\end{array}$ & $\begin{array}{c}0.021 \\
(0.063)\end{array}$ & $\begin{array}{c}-0.063 * * \\
(0.015)\end{array}$ & $\begin{array}{l}-0.002 \\
(0.010)\end{array}$ & $\begin{array}{l}0.065^{* *} \\
(0.015)\end{array}$ \\
\hline Stock index growth & $\begin{array}{c}0.002 \\
(0.022)\end{array}$ & $\begin{array}{l}0.345+ \\
(0.206)\end{array}$ & $\begin{array}{l}-0.042 \\
(0.035)\end{array}$ & $\begin{array}{c}0.031 \\
(0.021)\end{array}$ & $\begin{array}{c}0.010 \\
(0.011)\end{array}$ & $\begin{array}{l}-0.041 \\
(0.025)\end{array}$ \\
\hline IR index & $\begin{array}{l}-0.001 \\
(0.001)\end{array}$ & $\begin{array}{l}-0.010 \\
(0.007)\end{array}$ & $\begin{array}{l}-0.002 \\
(0.001)\end{array}$ & $\begin{array}{l}0.001+ \\
(0.001)\end{array}$ & $\begin{array}{c}0.000 \\
(0.000)\end{array}$ & $\begin{array}{l}-0.001 \\
(0.001)\end{array}$ \\
\hline Time & $\begin{array}{c}-0.038+ \\
(0.022)\end{array}$ & $\begin{array}{c}0.060 \\
(0.111)\end{array}$ & $\begin{array}{c}0.055 \\
(0.065)\end{array}$ & $\begin{array}{c}-0.026 * * \\
(0.005)\end{array}$ & $\begin{array}{l}0.008 * \\
(0.003)\end{array}$ & $\begin{array}{l}0.018 * * \\
(0.003)\end{array}$ \\
\hline Constant & & & & $\begin{array}{c}0.564 * * \\
(0.094)\end{array}$ & $\begin{array}{c}0.015 \\
(0.057)\end{array}$ & $\begin{array}{c}0.421 * * \\
(0.073)\end{array}$ \\
\hline Fixed effects & Yes & Yes & Yes & Yes & Yes & Yes \\
\hline $\begin{array}{l}\text { PIT marginal effects } \\
\text { (Unit) }\end{array}$ & $\begin{array}{c}-6.8 \\
\text { (percent) }\end{array}$ & $\begin{array}{c}84.9 \\
\text { (percent) }\end{array}$ & $\begin{array}{c}-2.7 \\
\text { (percent) }\end{array}$ & $\begin{array}{c}-2.5 \\
\text { (percent pt) }\end{array}$ & $\begin{array}{c}5.8 \\
\text { (percent pt) }\end{array}$ & $\begin{array}{c}-3.3 \\
\text { (percent pt) }\end{array}$ \\
\hline Observations & 1,324 & 325 & 860 & 156 & 156 & 156 \\
\hline Adj. R-squared & - & - & - & 0.690 & 0.774 & 0.575 \\
\hline Number of panel & 108 & 27 & 72 & 12 & 12 & 12 \\
\hline LL & -1126 & -188.4 & -750.5 & - & - & - \\
\hline
\end{tabular}

Note: This table presents regression analysis on the panel data constructed from the sample. "sp," "oc," and "jsc" stands for sole proprietors, other corporations, and joint-stock corporations, respectively. Columns (1)-(3) present fixed-effects Poisson estimates on the count of organizational types in a genealogy. Columns (4)-(6) present fixed-effects regression estimates on the share of organizational types in an industry. All specifications include industry-specific time trends. FE include regional dummies. FE Poisson includes the number of firms in a genealogy as an exposure variable. Clustered standard errors are in parentheses.

$* * p<0.01, * p<0.05,+p<0.1$.

Source: See Table 5.

other corporations. This magnitude implies that the number of other corporations increased by 84.9 percent, or by 0.048 firms per genealogy. The coefficient on $P I T_{t}$ takes a negative sign for joint-stock corporations, but is not statistically significant. The magnitudes of these estimates are harder to interpret since they are not directly comparable with those from the previous studies. Nonetheless, the results from this analysis indicate 
that time-invariant unobservable effects are unlikely to confound the earlier analysis.

Since a standard approach in recent studies is a panel regression analysis examining corporate shares aggregated over individual states or industries (de Mooij and Nicodeme 2008; Liu 2014), we aggregate the sample over 12 industries and examine corporate shares by industry-year in a fixed-effects regression model. The present study differs in using a subset of the population; due to data unavailability, we are unable to construct other measures of corporate activity like employment or output. While industry aggregation reduces the sample size substantially, these estimates provide a basis for comparison with results from the literature. We cluster standard errors within the panel unit (industry) and weight observations by the number of firms in industries.

Columns 4-6 of Table 6 show the result. In Column 10, the coefficient on $P I T_{t}$ in the model for other corporations is positive and statistically significant at the 1 percent level. The result indicates that the share of other corporations increased by 5.8 percentage points in the post-reform period. The coefficients on $P I T_{t}$ are not statistically significant for sole proprietorships, but the results likely reflect a lack of statistical power since the number of observations (156) is much smaller.

So far, the empirical framework implicitly assumed that the choice of organizational forms does not depend on firms' choices in the past. However, the decision likely exhibits time dependence for obvious reasons: firms would retain their current forms unless faced with a compelling reason to change. To obtain a sub-sample of firms with a continuous identity, we restrict the sample to observations with a single unit in a genealogy at a given time, and compute a transition matrix from each organizational type (sole proprietors, joint-stock corporations, other corporations) across adjacent years. The probabilities of remaining in the same type across years typically exceeded 98 percent in this sub-sample, indicating a strong dependence. Furthermore, the transition matrix also indicated that firms tend to "move up" from simpler organizational forms. However, since the off-diagonal elements were much smaller compared to the diagonal elements, the dynamic dependency seems the first-order importance in modeling. ${ }^{15}$

The industry panel readily extends to a dynamic analysis. In addition to including a lagged dependent variable in the fixed-effects estimation,

\footnotetext{
${ }^{15}$ A duration model may be more appropriate in modeling such behavior given this "irreversible" tendency, but the limited longitudinal information at firm level precludes us from implementing such model.
} 


\section{Taxes and the Choice of Organizational Form in Japan 463}

we employ difference and system General Method of Moments (GMM) estimation to incorporate a dynamic dependence while allowing for fixed effects and dynamic panel bias. For both difference and system GMM, we treat the macroeconomic control variables as predetermined but not strictly endogenous; collapse the instruments to avoid overfitting with numerous instruments (Roodman 2009); and use the one-step estimation procedure. We once again weight observations by the number of firms in the industries and cluster standard errors by industries.

Table 7 presents the main coefficient estimates, and all three models produce nearly identical coefficients on $P I T_{t}$. As is well documented, the dynamic panel bias affects the lagged dependent variable more severely compared to covariates (Judson and Owen 1999; Flannery and Hankins 2013). The coefficients on the lagged dependent variable are statistically significant at the 1 percent level across specifications and are larger under the GMM estimates, suggesting a high dynamic dependence with a possible dynamic panel bias under the fixed effects estimator. The similarity of the PIT coefficients across the three estimators, however, indicates that the fixed-effects model produces a robust estimate of the coefficient on PIT $_{t}{ }^{16}$ Our preferred estimates are therefore those in Columns 1-3. The coefficient on $P I T_{t}$ for the share of other corporations is 0.044 and is significant at the 1 percent level. Compared to the static model, this estimate is about 25 percent lower, but is higher than that implied by the baseline estimation employing the firm-level data.

\section{ALTERNATIVE EXPLANATIONS OF INCREASED INCORPORATION}

While we have explicitly controlled for economic factors in the analysis, without cross-section variation the identification could be confounded by other changes in the economy. We have noted that local governments started issuing decrees on incorporation around the time of the PIT introduction. If the creation of local rules increased the benefits of incorporation, perhaps through a better status of corporations, then an improved legal environment, rather than the tax motives, may better explain a rise in incorporation in 1887.

To address this concern, we examine Osaka prefecture, a commercial center during the Edo period, which issued a local guideline for establishing a corporation in February 1886. If the local rule was responsible

\footnotetext{
${ }^{16}$ Although the specification tests for the GMM estimators show that the instruments are valid with no second-order autocorrelation, the $p$-value for the Hansen test is one, which may be due to excessive instruments despite adopting a recommendation to reduce their number.
} 
TABLE 7

DYNAMIC PANEL REGRESSION USING THE INDUSTRY PANEL

\begin{tabular}{|c|c|c|c|c|c|c|c|c|c|}
\hline \multirow{3}{*}{$\begin{array}{l}\text { Estimator } \\
\text { Dependent Variable } \\
\text { Dependent Variable Code }\end{array}$} & (1) & (2) & (3) & (4) & (5) & (6) & (7) & (8) & (9) \\
\hline & \multicolumn{3}{|c|}{ Fixed Effects } & \multicolumn{3}{|c|}{ Difference GMM (DGMM) } & \multicolumn{3}{|c|}{ System GMM (SGMM) } \\
\hline & $\begin{array}{l}\text { Sole Prop. } \\
\text { sharesp }\end{array}$ & $\begin{array}{l}\text { Other Corp. } \\
\text { shareoc }\end{array}$ & $\begin{array}{c}\text { Joint Stock } \\
\text { sharejsc }\end{array}$ & $\begin{array}{l}\text { Sole Prop. } \\
\text { sharesp }\end{array}$ & $\begin{array}{c}\text { Other Corp. } \\
\text { shareoc }\end{array}$ & $\begin{array}{c}\text { Joint Stock } \\
\text { sharejsc }\end{array}$ & $\begin{array}{l}\text { Sole Prop. } \\
\text { sharesp }\end{array}$ & $\begin{array}{c}\text { Other Corp. } \\
\text { shareoc }\end{array}$ & $\begin{array}{c}\text { Joint Stock } \\
\text { sharejsc }\end{array}$ \\
\hline PIT Introduction & $\begin{array}{l}-0.022 \\
(0.025)\end{array}$ & $\begin{array}{c}0.044 * * \\
(0.010)\end{array}$ & $\begin{array}{l}-0.024 \\
(0.022)\end{array}$ & $\begin{array}{l}-0.023 \\
(0.025)\end{array}$ & $\begin{array}{c}0.043 * * \\
(0.009)\end{array}$ & $\begin{array}{l}-0.023 \\
(0.021)\end{array}$ & $\begin{array}{l}-0.022 \\
(0.026)\end{array}$ & $\begin{array}{c}0.043 * * \\
(0.010)\end{array}$ & $\begin{array}{l}-0.023 \\
(0.022)\end{array}$ \\
\hline Lagged dep. var. & $\begin{array}{l}0.412^{*} \\
(0.141)\end{array}$ & $\begin{array}{c}0.462 * * \\
(0.054)\end{array}$ & $\begin{array}{c}0.378 * * \\
(0.121)\end{array}$ & $\begin{array}{c}0.455^{* *} \\
(0.108)\end{array}$ & $\begin{array}{c}0.547 * * \\
(0.063)\end{array}$ & $\begin{array}{c}0.452 * * \\
(0.108)\end{array}$ & $\begin{array}{c}0.455 * * \\
(0.123)\end{array}$ & $\begin{array}{c}0.518 * * \\
(0.053)\end{array}$ & $\begin{array}{c}0.465 * * \\
(0.092)\end{array}$ \\
\hline Observations & 144 & 144 & 144 & 132 & 132 & 132 & 144 & 144 & 144 \\
\hline Number of panels & 12 & 12 & 12 & 12 & 12 & 12 & 12 & 12 & 12 \\
\hline Sargan test (p-val.) & - & - & - & 0.225 & 0.383 & 0.789 & 0.0767 & 0.315 & 0.751 \\
\hline Hansen test (p-val.) & - & - & - & 1.000 & 1.000 & 1.000 & 1.000 & 1.000 & 1.000 \\
\hline AR(2) test (p-val.) & - & - & - & 0.215 & 0.201 & 0.686 & 0.230 & 0.200 & 0.703 \\
\hline No. of instruments & - & - & - & 45 & 45 & 45 & 59 & 59 & 59 \\
\hline
\end{tabular}

Note: This table examines the robustness of results by including a lagged dependent variable in the industry panel regression on the share of organizational type. Three estimators include fixed effects (FE), difference GMM (DGMM), and system GMM (SGMM). For the GMM estimators, we treated the macroeconomic control variables as predetermined but not strictly endogenous, collapsed the instruments, and used the one-step estimation procedure. Observations are weighted by the number of firms in the industries, and standard errors, clustered at industry, are in parentheses.

$* * p<0.01, * p<0.05$.

Source: See Table 2. 

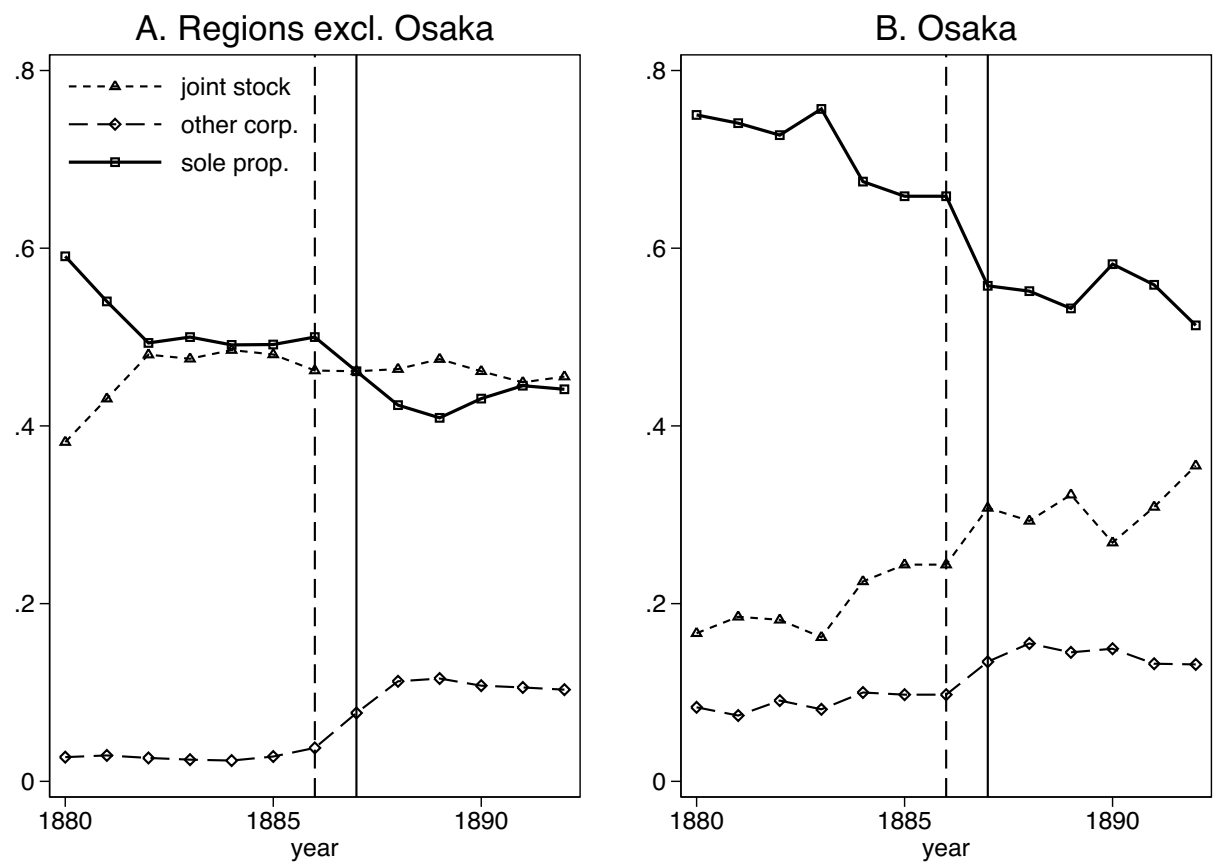

FIGURE 2

SHARES OF FIRMS BY ORGANIZATIONAL TYPES DURING THE SAMPLE PERIOD

Note: The solid vertical line indicates the introduction of PIT. The dotted vertical line indicates the year when Osaka prefecture issued a guideline on incorporation.

Source: See Table 2.

for the surge in incorporation, we should observe the incorporation rate in Osaka increase from 1885 to 1886. Panel B in Figure 2 shows shares of firms in Osaka Prefecture by organizational types. As a reference, Panel A shows for regions excluding Osaka. The dashed and solid vertical line indicates 1886 and 1887, respectively. Importantly, the incorporation rate did not increase from 1885 to 1886 in Osaka. Therefore, the data on Osaka do not support the concern about the local rule being important. The local guideline would have somewhat contributed to clarifying legal requirements for incorporation (Nakamura 2010), but is unlikely to explain the jump in incorporation rate in 1887.

If sales of government-managed assets coincided with the tax reform, our empirical approach would be compromised since buyers of government factories operated as corporations rather than sole proprietors. In 1880 , the government enacted a general guideline on sales of government factories, which required stringent financing requirements, including large upfront payments (Abe 2007, pp. 139-40). Sales of government factories occurred more widely at and after 1884, when the government 
abandoned these financing requirements due to a small pool of applicants. According to Takeshi Abe's (2007) tabulation of major sales of government factories, several factory sales preceded the introduction of PIT and occurred over time; year 1887 did not exhibit an abrupt break. Therefore, the sales of government factories would not confound the inference.

If the Bank of Japan (BOJ), which was founded in 1882, implemented some policy conducive to incorporation in 1887 , that might confound the inference. The BOJ, however, would have played a supportive role in fostering the industrial sector since at the time the central bank generally adhered to the principle of being the "bank of banks" (Tsurumi 1991). Earlier studies emphasized that the BOJ played a leading role at the time and established a view that it reigned over the financial institutions (Yoshino 1952; Ishii 1968). For instance, Toshihiko Yoshino (1952) documented high ratios of loans to deposits among national banks in the 1890s (a situation known an "over-loan" phenomenon), and argued that the BOJ played a significant role in inducing national banks to lend excessively. However, Masayoshi Tsurumi's (1991) examination of a large volume of historical documents edited and released by BOJ in the 1980s (BOJ 1982) revealed that BOJ played a complementary role in the Meiji financial system and did not dominate the market as much as previously emphasized. ${ }^{17}$

The primary influence of BOJ therefore would have been through setting the discount rates on commercial bills. In this view, the fact that the BOJ main office at Tokyo reduced the discount rate in the second half of 1886 and kept it low until the second half of 1888 may appear to be a concern with our identification strategy since this low-interest policy would have increased demand for founding new businesses. We have, however, included interest rates as a control variable, which should absorb this effect. Further, if this low-interest-rate policy induced the establishment of new corporations, the share of joint-stock corporations should increase over this period; in contrast, we do not observe a sudden break in the series for joint-stock corporations. Thus, the alternative explanation that some BOJ policy induced a surge in other types of corporations seems unlikely.

Finally, extra-territoriality continued during the period considered in this article and foreign investment and foreigner presence was important.

${ }^{17}$ BOJ started to take corporate stocks as collateral for lending to banks in 1890 (Tsurumi 1991). Such policy might appear to encourage incorporation, but a range of acceptable stocks was limited to well-established corporations particularly from the railroad sector. Moreover, the policy was not in place until later in the sample period. 


\section{Taxes and the Choice of Organizational Form in Japan 467}

If Japanese companies had an incentive to adopt a corporate form to facilitate dealings with foreigners and foreign companies, that might be responsible for the increase in corporations. The trades conducted at foreign settlements after the opening of ports were cash transactions so that a number of Japanese traders at the port drew their lineage from large merchants from the Edo Period (Sugiyama 2010). Those merchants listed by Shinya Sugiyama (2010) are not corporations, suggesting that the financial capacity, rather than the form of organization, would have been of first-order importance in participating in foreign trade. The textile industry is a case in point, having adopted corporate forms to finance larger trade volumes. For example, the share of lint imported by domestic corporations, such as Mitsui Bussan and Naigaimen, increased from less than 7 percent in 1885 to 60 percent in 1890 (Ōshima 2010), and joint financing of trade operations did appear to have played an important role. Our specification employs industry-specific trends, which absorb these sources of confounding influence.

\section{CONCLUSION AND DISCUSSION}

Economic historians named the period spanning the PIT introduction the "First Surge of the Corporate Sector" (1886-1889) in Japan (Nakamura 2010). Our study draws on a novel data source and utilizes the discrete change in tax law as a quasi-experiment to examine taxmotivated incorporation in nineteenth century Japan. The evidence shows that the introduction of PIT was an important factor behind the surge. Our estimates, while lower than those from some recent studies, would likely underestimate the true impact at the population level given the sample of prominent firms. In addition, our data are taken from an economy less developed than the United States in the early twentieth century. The tax administration in late nineteenth century Japan would have been much weaker, possibly enabling firms to substitute avoidance with evasion. While the discrepancy may in addition arise from nonlinear effects of PIT since many taxpayers may only respond to high tax rates, our results confirm findings in the existing literature that tax incentives affect small firms disproportionately. Specifically, the estimates show that the tax incentives affected the margin between sole proprietorship and "simpler" corporations but not joint-stock corporations.

More generally, our study demonstrates the role of the corporate income tax (CIT) as a backstop to the PIT, also emphasized in recent studies (de Mooij and Nicodème 2008; Liu 2014). The early PIT collected 
70 percent of projected revenue in the first year (Hayashi 1965), but the portion of this shortfall attributable to tax-motivated incorporation is hard to gauge from data available from the period under investigation. Rather, it would be relevant to examine further how PIT and CIT affect each other's revenue performance, as considered by Ruud de Mooij and Gaetan Nicodème (2008). Other things being constant, the introduction of CIT in 1899 would have reduced incorporation. PIT did not remain constant; however, the top rate for instance increased to 5.5 percent. This implies that tax incentives changed differentially by firm size. Large businesses faced stronger incentives to incorporate while smaller businesses faced incentives to be sole proprietors. To discern the impacts of the 1899 reform, one needs information on firm size since the impacts of this tax reform would have varied by size.

We leave several opportunities for quasi-experiments with later tax changes unexamined in the article, primarily because the advantage of genealogical data becomes less clear with the availability of aggregate statistics starting in the mid-1890s (Nicholas 2015). We are able, however, to capture the pre- and post-PIT period with our data, which provide a clearer sense of the initial impact of new tax policy. Moreover, qualitative evidence from the latter period suggests the importance of tax motives. Well-documented correspondence by managers of Mitsui zaibatsu reveal tax planning efforts that included a survey trip to Europe (Matsumoto 1979), and records of discussions from the National Assembly show a conscious development of anti-avoidance policies in the latter period (Takagi 2007). These questions would be fruitful extensions for future work.

Finally, our sample consists of existing firms as well as newly formed firms. To the extent that existing firms face switching costs, the response among existing firms should be sluggish compared to new firms which do not face switching costs. Our estimates, as well as those from previous studies, are the weighted averages of responses from incumbents and newcomers. Earlier scholarship may have neglected the distinction between incumbents and newcomers because the combined effects are more relevant in assessing the impact on revenues. However, in assessing the efficiency consequence, particularly on decisions made by start-up firms, we need to know the degree to which newcomers respond to tax incentives. Put differently, if incumbents incur extra costs of changing organizational forms, the existing estimates understate how much taxes influence new firms' organizational-form decisions. Distinguishing the responses of incumbents and newcomers would be a promising avenue for further investigation. 


\section{Taxes and the Choice of Organizational Form in Japan 469}

\section{Data Appendix}

Appendix Table 1 lists sources of key variables used in this article's analysis. GDP is from the Japan Statistical Association (1987). For the price level, we employ the general price level listed in Nakazawa (2001), rather than prices of rice. Nakazawa (2001) contains annual figures of general price level, stock index, and interest rates for the sample period, except that interest rates for latter sample years were available for multiple months. For those years, we averaged the figures.

\begin{tabular}{|c|c|c|c|}
\hline \multicolumn{4}{|c|}{$\begin{array}{l}\text { APPENDIX TABLE } 1 \\
\text { VARIABLE LIST }\end{array}$} \\
\hline Variable & Code & Description & Source \\
\hline Sole proprietor & $\mathrm{sp}$ & $\begin{array}{l}\text { Indicator for observation } i \\
\text { being a sole proprietor }\end{array}$ & $\begin{array}{l}\text { Authors' computation } \\
\text { based on the genealogies } \\
\text { in Yagura and Ikushima } \\
\text { (1986) }\end{array}$ \\
\hline $\begin{array}{l}\text { Joint-stock } \\
\text { corporations }\end{array}$ & jsc & $\begin{array}{l}\text { Indicator for observation } \\
i \text { being a joint-stock } \\
\text { corporation }\end{array}$ & As above \\
\hline Other corporations & oc & $\begin{array}{l}\text { Indicator for observation } i \\
\text { being a partnership, limited } \\
\text { partnership, or limited } \\
\text { liability corporation }\end{array}$ & As above \\
\hline $\begin{array}{l}\text { PIT } \\
\text { Introduction }\end{array}$ & pit & $\begin{array}{l}\text { Indicator for observations } \\
\text { with } t \text { at or greater than } \\
1887\end{array}$ & As above \\
\hline Industry growth & numgr & $\begin{array}{l}\text { The growth rate of the } \\
\text { number of firms in industry } j\end{array}$ & As above \\
\hline Age & age & $\begin{array}{l}\text { The number of years since } \\
\text { the foundation of the first } \\
\text { firm in a genealogy until } t\end{array}$ & As above \\
\hline GDP growth & gdpgr & $\begin{array}{l}\text { GDP growth rate, deflated } \\
\text { by the price level }\end{array}$ & $\begin{array}{l}\text { Japan Statistical } \\
\text { Association (1987, } \\
\text { Table 13-03) }\end{array}$ \\
\hline Price level & priceindex & General price level & $\begin{array}{l}\text { Nakazawa } \\
(2001)\end{array}$ \\
\hline Stock index growth & stockgr & $\begin{array}{l}\text { The year-on-year growth } \\
\text { rate of stock index }\end{array}$ & As above \\
\hline IR index & ririndex & $\begin{array}{l}\text { Daily interest in } 1 / 100 \\
\text { yen, deflated by the price } \\
\text { level and indexed to } 1868 \text {. } \\
\text { When multiple records were } \\
\text { available within a year, we } \\
\text { used an average }\end{array}$ & As above \\
\hline
\end{tabular}




\section{REFERENCES}

Abe, Takeshi. "Kindai keiei no keisei: Meiji zenki/chūki no kigyōkeiei [Formation of modern management: Corporate management of the early and mid Meiji Period]." In Nihon keieishi: Edo jidai kara 21 seiki e [Japanese business history: From the Edo dynasty to 21st century], edited by Matao Miyamoto, Takeshi Abe, Masaru Udagawa, Minoru Sawai, and Takeo Kikkawa. Tokyo: Yūhikaku, 2007.

Bank of Japan. Nihon Ginkō Hyakunen shi [The Bank of Japan: One Hundred Years' History], Volume 1. Tokyo: Bank of Japan, 1982.

Cullen, Julie B., and Roger H. Gordon. "Taxes and Entrepreneurial Risk-Taking: Theory and Evidence for the US.” Journal of Public Economics 91, no. 7 (2007): 1479-505.

de Mooij, Ruud, and Gaetan Nicodème. "Corporate Tax Policy and Incorporation in the EU.” International Tax and Public Finance 15, no. 4 (2008): 478-98.

Flannery, Mark J., and Kristine W. Hankins. "Estimating Dynamic Panel Models in Corporate Finance." Journal of Corporate Finance 19 (2013): 1-19.

Freedman, Judith, and Claire Crawford. "Small Business Taxation." In Dimensions of Tax Design: The Mirrlees Review, edited by Institute for Fiscal Studies. Oxford: Oxford University Press, 2010.

Fruin, W. Mark. The Japanese Enterprise System: Comparative Strategies and Cooperative Structures. Oxford: Clarendon Press, 1994.

Goolsbee, Austan. "Taxes, Organizational Form, and the Deadweight Loss of the Corporate Income Tax." Journal of Public Economics 69, no. 1 (1998): 143-152.

_ . "The Impact of the Corporate Income Tax: Evidence from State Organizational Form Data.” Journal of Public Economics 88, no. 11(2004): 2283-99.

Gordon, Roger H., and Jeffrey K. MacKie-Mason. "Tax Distortions to the Choice of Organizational Form.” Journal of Public Economics 55, no. 2 (1994): 279-306.

Grossfeld, Bernhard, and James D. Bryce. "Brief Comparative History of the Origins of the Income Tax in Great Britain, Germany and the United States." American Journal of Tax Policy 2 (1983): 211-52.

Hanlon, Michelle, and Shane Heitzman. "A Review of Tax Research." Journal of Accounting and Economics 50, no. 2 (2010): 127-78.

Hayashi, Takehisa. Nihon ni okeru sozei kokka no seiritsu [Establishment of the modern taxation and state in Japan]. Tokyo: Tokyo University Press, 1965.

Ishii, Kanji. "Sangyō shihon kakuritsu katei ni okeru nihon ginkō shinyō no igi [The role of credit creation by the Bank of Japan during the development of industrial capital]." In Nihon Keizaishi [Japanese Economic History], edited by Kazuo Yamaguchi. Tokyo: Chikuma Shobō, 1968.

Japan Statistical Association. Nihon chōki tōkei sōran [Historical statistics of Japan]. Tokyo: Nihon Tōkei Kyōkai, 1987.

Japanese Bankers Association. Database of bank transition history. Retrieved from http://www.zenginkyo.or.jp/library/hensen/. Accessed 1 June 2012.

Judson, Ruth A., and Ann L. Owen. "Estimating Dynamic Panel Data Models: A Guide for Macroeconomists.” Economics Letters 65, no. 1 (1999): 9-15.

Liu, Li. "Income Taxation and Business Incorporation: Evidence from the Early Twentieth Century." National Tax Journal 67, no. 2 (2014): 387-418.

Mackie-Mason, Jeffrey K., and Roger H. Gordon. "How Much Do Taxes Discourage Incorporation?" Journal of Finance 52, no. 2 (1997): 477-506. 


\section{Taxes and the Choice of Organizational Form in Japan 471}

Maruyama, Takemitsu. Nihon chihō zeiseishi [History of regional taxes in Japan]. Tokyo: Gyōsei, 1985.

Matsumoto, Hiroshi. Mitsubishi zaibatsu no kenkyū [Study of Mitsubishi zaibatsu]. Tokyo: Kikkawa Bunko, 1979.

Miyamoto, Matao. "Sangyōka to kaisha seido no hatten [Industrialization and the development of company institution]." In Sangyōka no jidai [Era of industrialization], edited by Shunsaku Nishikawa and Takeshi Abe. Tokyo: Sansuisha, 1990.

Morikawa, Hidemasa. Zaibatsu: The Rise and Fall of Family Enterprise Groups in Japan. Tokyo: University of Tokyo Press, 1992.

Nakamura, Naofumi. "Nihon ni okeru kindai kigyō no seisei [Development of modern corporations in Japan]." In Sangyō kakumei to kigyō keiei: 1882-1914 [Industrial revolution and business administration: 1882-1914], edited by Takeshi Abe and Naofumi Nakamura. Tokyo: Minerva Shobō, 2010.

Nakazawa, Benjirō. Nihon beika hendōshi [The history of rice price fluctuation in Japan]. Tokyo: Kashiwa Shobō, 2001.

Nicholas, Tom. "The Organization of Enterprise in Japan." Journal of Economic History 75, no. 2 (2015): 333-63.

Ōshima, Hisayuki. "Sōgō shōsha no tenkai [Development of general trading companies]." In Sangyō kakumei to kigyō keiei: 1882-1914 [Industrial revolution and business administration: 1882-1914], edited by Takeshi Abe and Naofumi Nakamura. Tokyo: Minerva Shobō, 2010.

Okazaki, Tetsuji, Yasushi Hamao, and Takeo Hoshi. "The Genesis and the Development of the Pre-War Japanese Stock Market." Keizai Kenkyū 56, no. 1 (2005): $15-29$.

Orii, Kiyoshi, and Hiroshi Yamamoto. "Souseiki no shotokuzei soukō [The origin of income tax]." Zeidai Ronsō 20 (1990): 1-376.

Romer, Christine D., and David H. Romer. "The Incentive Effects of Marginal Tax Rates: Evidence from the Interwar Era." American Economic Journal: Economic Policy 6, no. 3 (2014): 242-81.

Roodman, David. "A Note on the Theme of Too Many Instruments." Oxford Bulletin of Economics and Statistics 71, no. 1 (2009): 135-58.

Sugiyama, Shinya. "Gaikoku shōnin no katudou [Activities of foreign merchants]." In Sangyō kakumei to kigyō keiei: 1882-1914 [Industrial revolution and business administration: 1882-1914], edited by Takeshi Abe and Naofumi Nakamura. Tokyo: Minerva Shobō, 2010.

Takagi, Katsuichi. Nihon shotokuzei hatten shi: Shotokuzei kaikaku no hatten to rekishi, sōseiki kara genzai made [The development of the Japanese income tax: History and development of income tax reforms from the foundation to present]. Tokyo: Gyōsei, 2007.

Takahashi, Kamekichi. Waga kuni kigyō no shiteki hatten [The historical development of the corporate sector in Japan]. Tokyo: Tōyōkeizai Shinpōsha, 1956.

Tang, John P. "Technological Leadership and Late Development: Evidence from Meiji Japan, 1868-1912.” Economic History Review 64, no. S1 (2011): 99-116.

- "Financial Intermediation and Late Development in Meiji Japan, 1868 to 1912." Financial History Review 20, no. 02 (2013): 111-35.

- "Railway Expansion and Industrialization: Evidence from Meiji Japan." Journal of Economic History 74, no. 3 (2014): 863-86. 
_ . "A Tale of Two SICs: Japanese and American Industrialisation in Historical Perspective." Australian Economic History Review 56, no. 2 (2016): 174-97.

Tōyō Keizai Shinpōsha. Meiji Taishō Kokusei Sōran [A Compendium of Censuses from Meiji and Taisho]. Tokyo: Tōyō Keizai Shinpōsha, 1975.

Tsurumi, Masayoshi. Nihon shinyō kikō no kakuritsu: Nihon ginkō to kinyū shijyō [Establishment of financial system in Japan: Bank of Japan and financial market]. Tokyo: Yūhikaku, 1991.

Wooldridge, Jeffrey M. Econometric Analysis of Cross Section and Panel Data. Cambridge: The MIT Press, 2010.

Yagura, Shintarō, and Yoshirō Ikushima. Shuyō kigyō no keifuzu [Genealogical charts of Japanese major corporations]. Tokyo: Yushōdō, 1986.

Yoshida, Junzō. Nihon no kaishaseido hattatsushi no kenkyū [The history of corporate institution in Japan]. Tokyo: Ryūtū Keizai University Press, 1998.

Yoshino, Toshihiko. "Waga kuni shichū ginkō no ōbārōn ni tuite [On the over loan of Japanese private banks]." Nihon Ginkō Chōsa Geppo [Bank of Japan Survey Monthly Bulletin], Tokyo: Bank of Japan, February 1952. 